\title{
PENGARUH EDUKASI GIZI TERHADAP FEEDING PRACTICE PADA IBU DENGAN BALITA STUNTING DI PUSKESMAS SIMPANG AGUNG KECAMATAN SEPUTIH AGUNG KABUPATEN LAMPUNG TENGAH
}

\author{
Linawati Novikasari ${ }^{1}$, Livia Eka Fitriana ${ }^{2}$
}

\author{
1Dosen Program Studi Keperawatan Universitas Malahayati \\ Email : lina.novika@yahoo.com \\ ${ }^{2}$ Mahasiswa Program Studi Keperawatan Universitas Malahayati \\ Email : liviaekafitirana88@gmail.com
}

\section{ABSTRACT : THE EFFECT OF NUTRITIONAL EDUCATION ON FEEDING PRACTICE IN MOTHER WITH STUNTING CHILDREN AT PUSKESMAS SIMPANG AGUNG KECAMATAN SEPUTIHAGUNG KABUPATEN LAMPUNG MIDDLE}

Background : Nutrition is one of the factors that determine the success of achieving optimal growth and development during toddlerhood. The golden period of growth requires proper nutritional support. Good nutrition will speed up recovery and reduce the intensity (emergency) of infectious diseases in toddlers.

Purpose : Of this study was to determine the effect of nutrition education on feeding practice in mothers with stunted children at the Simpang Agung Public Health Center, Seputih Agung District, Central Lampung Regency, 2020.

Method : The type of research used in this research is quantitative with the design in this study using a Quasi Experiment using the One Group Pretest Postest approach. The population in this study were all mothers who had children under five with a total of 30 mothers with a total sample of 30 mothers. In this study the sampling technique used was the total population, this is because the available population $<100$ respondents

Result : Based on statistical tests, it is known that the $p$-value is 0,000 or $p$-value $<0.05$, which means the effect of nutritional education on feeding practice in mothers with stunting children at the Simpang Agung Public Health Center, Seputih Agung District, Central Lampung Regency in 2020.

Conclusion : It is known that at Simpang Agung Public Health Center, Seputih Agung District, Central Lampung Regency in 2020, the average Feeding Practice before being given nutrition education was 27.13 with a standard deviation of 8.978 and a standard error of 1.639 , while after being given nutrition education the average Feeding Practice was 40.83 with a standard deviation of 10.923 and a standard error of 1.994. It is known that based on the average results before and after, the difference is 13,700 .

Keywords : Nutrition Education \& Feeding Practice 


\section{INTISARI : PENGARUH EDUKASI GIZI TERHADAP FEEDING PRACTICE PADAIBU DENGAN BALITA STUNTING DI PUSKESMAS SIMPANG AGUNG KECAMATAN SEPUTIH AGUNGKABUPATEN LAMPUNG TENGAH}

Pendahuluan : Gizi merupakan salah satu faktor yang menentukan keberhasilan untuk mencapai tumbuh kembang optimal pada masa balita. Periode emas pertumbuhan memerlukan dukungan gizi yang tepat. Gizi yang baik akan mempercepat pemulihan dan mengurangi intensitas (kegawatan) penyakit infeksi pada balita.

Tujuan : Dalam penelitian ini adalah diketahui Pengaruh Edukasi Gizi Terhadap Feeding Practice pada Ibu dengan Balita Stunting Di Puskesmas Simpang Agung Kecamatan Seputih Agung Kabupaten Lampung Tengah Tahun 2020

Metode : Jenis penelitian yang digunakan dalam penelitian ini adalah kuantitatif dengan rancangan dalam penelitian ini menggunakan Quasi Eksperimen dengan menggunakan pendekatan One Group Pretes Postest. Populasi dalam penelitian ini adalah seluruh ibu yang mempunyai balita Stunting yang berjumlah 30 ibu dengan jumlah sampel berjumlah 30 ibu. Dalam penelitian ini teknik sampling yang digunakan adalah total populasi, hal ini dikarenakan populasi yang tersedia $<100$ responden

Hasil : Berdasarkan uji statistic, diketahui p-value 0,000 atau p-value $<0,05$, yang artinya Pengaruh Edukasi Gizi Terhadap Feeding Practice pada Ibu dengan Balita Stunting Di Puskesmas Simpang Agung Kecamatan Seputih Agung Kabupaten Lampung Tengah Tahun 2020

Kesimpulan : Diketahui bahwa Di Puskesmas Simpang Agung Kecamatan Seputih Agung Kabupaten Lampung Tengah Tahun 2020, rata-rata Feeding Practice sebelum diberikan edukasi gizi adalah 27,13 dengan standar deviasi 8,978 dan standar eror 1,639, sedangkan sesudah diberikan edukasi gizi rata rata Feeding Practice adalah 40,83 dengan standar deviasi 10,923 dan standar error 1,994. Diketahui berdasarkan hasil rata-rata sebelum dan sesudah, nilai selisihnya adalah 13,700 .

Kata Kunci : Edukasi Gizi \& Feeding Practice

\section{PENDAHULUAN}

Menurut WHO (World Health Organization) tahun 2016 jumlah balita mencapai 34 ribu juta jiwa, sedangkan Indonesia sendiri mempunyai jumlah balita hingga mencapai 990 juta jiwa, berdasarkan angka cakupan status gizi pada balita, status gizi balita dapat diukur dengan indeks berat badan per umur $(\mathrm{BB} / \mathrm{U})$, tinggi badan per umur $(T B / U)$ dan berat badan per tinggi badan ( $\mathrm{BB} / \mathrm{TB})$. Berdasarkan pemantauan status gizi (PSG) tahun 2017 yang diselenggarakan oleh Kementrian Kesehatan menyatakan bahwa persentase gizi buruk pada balita usia 0-59 bulan di Indonesia hasil PSG tahun 2015 yaitu persentase gizi buruk pada balita usia 0-59 bulan sebesar 2,85\% dan persentase gizi kurang sebesar 13,20\%. Pada tahun 2016 yaitu persentase gizi buruk pada balita usia 0-59 bulan sebesar 3,4\% dan persentase gizi kurang sebesar 14,43\%, sedangkan PSG tahun 2017 balita usia 0-59 bulan yang mengalami gizi buruk adalah 3,8\%, dan persentase gizi kurang adalah 14\%. Provinsi dengan persentase tertinggi gizi buruk dan gizi kurang pada balita usia 0-59 bulan tahun 2017 adalah Nusa Tenggara Timur, sedangkan provinsi dengan 
persentase terendah adalah provinsi Bali (Kemenkes, RI. 2017).

Gagal tumbuh biasanya mulai terjadi di usia empat bulan yang berlanjut sampai usia dua tahun. Deteksi dini sangat penting untuk mencegah terjadinya masalah gizi salah satunya melalui pemantauan pertumbuhan balita di posyandu. Keberhasilan program pemantauan pertumbuhan balita bisa dilihat dari pencapaian kenaikan berat badan dari balita yang datang menimbang ke posyandu (N/D) setiap bulannya. Tahun 2018 pencapaian N/D sebesar $85,2 \%$. Balita yang kenaikan berat badannya tidak mengikuti garis pertumbuhan atau kenaikan berat badan kurang dari kenaikan berat badan minimal maka dikatakan balita tersebut tidak naik berat badannya (T) Tahun 2018 balita yang tidak naik berat badannya adalah sebesar 4,85\% (Kemenkes, RI. 2017).

Berdasarkan data dari Dinas Kesehatan Provinsi Lampung, menunjukkan bahwa, jumlah anak balita usia 0-24 bulan mencapai 14.172 anak, dan anak yang mengalami stunting mencapai $12,59 \%$, sedangkan untuk Kabupaten Lampung Tengah, terhitung sejak Januri - Desember 2018, jumlah anak usia 0-24 bulan mencapai 2.511, dimana yang mengalami stunting mencapai 933 anak (Profil Dinkes Provinsi Lampung, 2018)

Penelitian mengenai faktor yang berkontribusi terhadap kejadian stunting pada balita 0-24 bulan sudah banyak dilakukan. Faktor yang berkontribusi terhadap stunting tersebut adalah tinggi badan ayah; riwayat berat badan lahir rendah; riwayat gizi kurang; kurangnya pemanfaatan posyandu dan perilaku higiene; ketidaksesuaian dalam pemberian makanan pendamping dan pelengkap serta secara kuantitas dan kualitas gizi makanan yang diberikan kurang; praktik menyusui dan praktik pemberian makan Menurut kajian Unicef Indonesia, terdapat berbagai hambatan yang menyebabkan tingginya angka balita stunting usia 0-24 bulan di Indonesia. Salah satu hambatan utamanya adalah pengetahuan yang tidak memadai dan praktik-praktik gizi yang tidak tepat. Secara khusus dijelaskan bahwa pengetahuan dan praktik yang menjadi hambatan utama adalah pemberian ASI ekslusif yang masih sangat kurang dan rendahnya pemberian makanan pendamping yang sesuai (41\%) (Kemenkes, RI. 2017).

Pemberian makan yang yang terlambat oleh ibu akan berdampak kepada kekurangan zat besi dan zinc pada bayi yang dalam penelitian ini hal tersebut tidak dikaji. Intervensi edukasi gizi mencakup pemberian pengetahuan dan pemberian motivasi ke arah perubahan sikap dan perilaku pemberian makan. Edukasi gizi dengan media berupa booklet dan contoh langsung (food sample) akan lebih mudah dipahami oleh subjek penelitian karena menarik perhatian dan tidak membosankan. Hal ini diperlihatkan oleh kedua kelompok melalui peningkatan skor pengetahuan dan feeding practice. Menurut ahli indera, $75 \%$ hingga $87 \%$ pengetahuan manusia disalurkan melalui indera pandang (Kemenkes, RI. 2017).

Feeding Practice merupakan salah satu pratik dalam memberikan menu makanan yang diberikan kepada anak dengan jumlah zat gizi yang dibutuhkan oleh anak, salah satu kelemahan para ibu dalam memberikan menu makanan pada anak adalah kurangnya ketepatan menu makanan yang diberikan kepada anak terhadap usia anak. Feeding practice sangat mempengaruhi pertumbuhan dan perkembangan anak, dengan konsep atau praktik yang salah maka anak akan mengalami kekurangan gizi 
bahkan akan mengalami gagal pertumbuhan dan perkembangan, seperti halnya dapat menyebabkan stunting, dilain sisi beberapa manfaat feeding practice adalah meningkatkan status gizi anak, meningkatkan imunitas anak, mendukung program pemerintah dalam menangani gizi buruk anak serta menciptakan keluarga yang sehat dan sejahtera (Maryunani, 2016).

Menurut penelitian Maryati Dewi, dkk tentang Pengaruh Edukasi Gizi terhadap Feeding Practice Ibu Balita Stunting Usia 6-24 Bulan, menyebutkan bahwa, hasil penelitian didapatkan bahwa terdapat perbedaan rerata yang bermakna pada skor pengetahuan sebelum dan setelah intervensi pada kedua kelompok $(p=0,006 ; p=0,003)$, terdapat perbedaan rerata yang bermakna pada skor feeding practice sebelum dan setelah intervensi pada kedua kelompok ( $p=0,002 ; p=0,05)$. Menurut data Dinas Kesehatan Kabupaten Lampung Tengah, pada tahun 2017 angka kejadian stunting pada balita mencapi $12,2 \%$ dari 23.210 balita, dan meningkat pada tahun 2018 hingga mencapi $14.6 \%$ dari 23.433 balita (Profil Dinkes Kabupaten Lampung Tengah, 2018)

Berdasarkan data prasurvey pada tanggal 16 Maret $2020 \mathrm{Di}$ Puskesmas Simpang Agung Kecamatan Seputih Agung Kabupaten Lampung Tengah, terdapat 20 ibu yang mempunyai bayi balita usia 0-24 bulan, dimana dari 20 anak tersebut, ada 10 anak yang mengalami stunting. Berdasarkan data wawancara diketahui bahwa dari 10 ibu (100\%) tidak pernah mendapatkan edukasi tentang gizi dan mereka tidak mengetahui cara memberikan makanan yang tepat dan bergizi, dan berdasarkan wawancara juga diketahui ada 10 ibu (100\%) yang tidak mengetahui tentang feeding practice, hal ini dikarenakan $4 \mathrm{ibu}$ (40\%) mempunyai pendidikan rendah, 4 ibu (40\%) mempunyai usia < 20 tahun, dan 2 ibu (20\%) baru menjalani kehamilan pertama (primipara).

Berdasarkan masalah di atas penulis tertarik untul mengambil penelitian dengan judul "Pengaruh Pemberian Edukasi Gizi Terhadap Feeding Practice Pada ibu dengan balita stunting Di Puskesmas Simpang Agung Kecamatan Seputih Agung Kabupaten Lampung Tengah Tahun 2020".

\section{METODELOGI PENELITIAN}

Rancangan dalam penelitian ini menggunakan survei analitik dengan menggunakan pendekatan cross sectional yaitu peneliti mendatangi ibu dengan bayi secara langsung untuk pengambilan data pada saat itu juga. Populasi dalam penelitian ini adalah seluruh ibu yang mempunyai balita Di Wilayah Kerja Puskesmas Simpang Agung Kecamatan Seputih Agung Kabupaten Lampung Tengah pada bulan Juni 2020 yang berjumlah 30 ibu, Dalam penelitian ini teknik sampling yang digunakan adalah total sampling. Tempat penelitian dilakukan Di Puskesmas Simpang Agung Kecamatan Seputih Agung Kabupaten Lampung Tengah. Dengan keterangan kelaikan etik dengan no. 992/EC/KEP-UNMALVII/ 2020. Instrumen penelitian adalah alat yang digunakan untuk mengumpulkan data dalam penelitian ini lembar kuesioner dengan jumlh 15 soal.

Uji normalitas dalam pengujian data ini menggunakan ketentuan Shapiro-Wilk dikarenakan data $\leq 50$. 
Tabel 1. Uji Normalitas

\begin{tabular}{|c|c|c|c|}
\hline \multirow{2}{*}{$\begin{array}{l}\text { Edukasi } \\
\text { Gizi }\end{array}$} & \multicolumn{3}{|c|}{ Shapiro-Wilk } \\
\hline & $\begin{array}{c}\text { Statisti } \\
\mathrm{C}\end{array}$ & $\mathrm{Df}$ & Sig. \\
\hline \multirow{2}{*}{$\begin{array}{l}\text { Feeding } \\
\text { Practice }\end{array}$} & 0,640 & 10 & 0,326 \\
\hline & 0,544 & 20 & 0,411 \\
\hline
\end{tabular}

diketahui bahwasanya nilai $\mathrm{p}$-value untuk Shapiro Wilk adalah > 0,05, sehingga data yang peneliti gunakan berdistribusi normal.

Dalam penelitian ini menggunakan analisa univariat dan bivariat, analisis univariat menggunakan rumus presentase, Analisis bivariat digunakan untuk melihat pengaruh edukasi gizi terhadap feeding practice. Dalam penelitian ini peneliti menggunakan uji-Paired T-Test, yang dilakukan terhadap dua variabel, apabila $p$ value $<0,05$, maka Ha diterima, dan apabila $p$-value $>0,05$, maka $\mathrm{Ha}$ di tolak

\section{HASIL PENELITIAN}

Karateristik Responden

Tabel 2. Distribusi Frekuensi umur, Pendidikan dan pekerjaan Responden Di Puskesmas Simpang Agung Kecamatan Seputih Agung Kabupaten Lampung Tengah Tahun 2020

Analisis Univariat

Tabel 3 Rata-Rata Feeding Practice Balita Stunting Sebelum Diberikan Edukasi Gizi

\begin{tabular}{lcccccc}
\hline Variabel & $\mathrm{N}$ & Mean & Minimum & Maksimum & SD & SE \\
\hline Sebelum & 30 & 27,13 & 17 & 22 & 8,978 & 0,427 \\
\hline
\end{tabular}

Berdasarkan tabel 3, diketahui bahwa Di Puskesmas Simpang Agung Kecamatan Seputih Agung Kabupaten Lampung Tengah Tahun

\begin{tabular}{ccc}
\hline $\begin{array}{l}\text { Usia } \\
\text { Responden }\end{array}$ & Frekuensi & $\begin{array}{c}\text { Persentase } \\
\text { (\%) }\end{array}$ \\
\hline 25 - 32 Tahun & 18 & 60,0 \\
33 - 43 Tahun & 12 & 40,0 \\
\hline Pekerjaan & & \\
\hline Buruh & 14 & 46.7 \\
PNS & 1 & 3.3 \\
Swasta & 3 & 10.0 \\
Wiraswasta & 12 & 40.0 \\
Buruh & 14 & 46.7 \\
\hline Pendidikan & & \\
\hline D3 & 4 & 13.3 \\
S1 & 1 & 3.3 \\
SD & 7 & 23.3 \\
SMA & 10 & 33.3 \\
SMP & 8 & 26.7 \\
\hline Jumlah & 30 & 100.0 \\
\hline
\end{tabular}

Berdasarkan tabel 2, diketahui bahwa Di Puskesmas Simpang Agung Kecamatan Seputih Agung Kabupaten Lampung Tengah Tahun 2020, sebagian besar responden berusia 25 - 32 tahun berjumlah 18 responden $(60,0 \%)$. sebagian besar responden mempunyai pekerjaan sebagai buruh yang berjumlah 14 responden $(46,7 \%)$. Sebagian besar responden mempunyai pendidikan SMA yang berjumlah 10 responden $(33,3 \%)$.

Tabel 4. Rata-Rata Feeding Practice Balita Stunting Usia 6-24 Bulan Sesudah Diberikan Edukasi Gizi

\begin{tabular}{lcccccc}
\hline Variabel & N & Mean & Minimum & Maksimum & SD & SE \\
\hline Sesudah & 30 & 40,83 & 46 & 59 & 10,923 & 0,27 \\
\hline
\end{tabular}


Berdasarkan tabel 4, diketahui bahwa Di Puskesmas Simpang Agung Kecamatan Seputih Agung Kabupaten Lampung Tengah Tahun 2020 , Rata-Rata Feeding Practice Balita Stunting Sesudah Diberikan Edukasi Gizi adalah 40,83.

\section{Analisis Bivariat}

Tabel 5 Pengaruh Pemberian Edukasi Gizi Terhadap Feeding Practice Ibu Balita Stunting Di Puskesmas Simpang Agung Kecamatan Seputih Agung Kabupaten Lampung Tengah Tahun 2020

\begin{tabular}{lcccccc}
\hline Variabel & N & Mean & Selisih & SD & SE & $\begin{array}{c}\text { P- } \\
\text { Value }\end{array}$ \\
\cline { 1 - 1 } Feeding Practice Sebelum & & 27,13 & & 8,978 & 1,639 & 0,000 \\
\cline { 1 - 1 } Feeding Practice Sesudah & 40,83 & $-13,700$ & 10,923 & 1,994 & \\
\hline
\end{tabular}

Berdasarkan tabel 5, diketahui bahwa Di Puskesmas Simpang Agung Kecamatan Seputih Agung Kabupaten Lampung Tengah Tahun 2020, rata-rata Feeding Practice sebelum diberikan edukasi gizi adalah 27,13 dengan standar deviasi 8,978 dan standar eror 1,639, sedangkan sesudah diberikan edukasi gizi rata rata Feeding Practice adalah 40,83 dengan standar deviasi 10,923 dan standar error 1,994. Diketahui berdasarkan

\section{PEMBAHASAN}

\section{Feeding Practice Sebelum Diberikan Edukasi Gizi}

Edukasi gizi Edukasi gizi menurut Fikawati (2012) adalah suatu proses yang berkesinambungan untuk menambah pengetahuan tentang gizi, membentuk sikap dan perilaku hidup sehat dengan memperhatikan pola makan seharihari dan faktor

lain yang mempengaruhi makanan, serta meningkatkan derajat kesehatan dan gizi seseorang. Tujuan dari pemberian edukasi gizi
Untuk mengetahui Pengaruh Pemberian Edukasi Gizi Terhadap Feeding Practice Ibu Balita Stunting Di Puskesmas Simpang Agung Kecamatan Seputih Agung Kabupaten Lampung Tengah Tahun 2020, menggunakan (Paired Sample T-Test), yaitu: 
penyuluhan, Menyusun rencana penilaian (evaluasi) dan Menyusun rencana kerja atau rencana pelaksanaan.

Berdasarkan hasil penelitian dan teori diatas, sejalan dengan penelitian Arum Anggraini (2016) tentang pengaruh pemberian edukasi gizi terhadap perilaku pemberian makanan pada bayi Di Wilayah Kerja Puskesmas Srengsem Jawa Timur, menyebutkan bahwa rata-rata sebelum diberikan edukasi gizi perilaku pemberian makan adalah 34,22.

Berdasarkan hasil penelitian dan pembahasan diatas, maka menurut peneliti sebelum diberikan edukasi gizi rata-rata feeding practice ibu dengan balita $\mathrm{Di}$ Puskesmas Simpang Agung Kecamatan Seputih Agung Kabupaten Lampung Tengah Tahun 2020 , Rata-Rata Feeding Practice Balita Stunting Usia 6-24 Bulan Sebelum Diberikan Edukasi Gizi adalah 27,13.

\section{Feeding Practice Sesudah Diberikan Edukasi Gizi}

Feeding Practice merupakan salah satu pratik dalam memberikan menu makanan yang diberikan kepada anak dengan jumlah zat gizi yang dibutuhkan oleh anak, salah satu kelemahan para ibu dalam memberikan menu makanan pada anak adalah kurangnya ketepatan menu makanan yang diberikan kepada anak terhadap usia anak. Feeding practice sangat mempengaruhi pertumbuhan dan perkembangan anak, dengan konsep atau praktik yang salah maka anak akan mengalami kekurangan gizi bahkan akan mengalami gagal pertumbuhan dan perkembangan, seperti halnya dapat menyebabkan stunting, dilain sisi beberapa manfaat feeding practice adalah meningkatkan status gizi anak, meningkatkan imunitas anak, mendukung program pemerintah dalam menangani gizi buruk anak serta menciptakan keluarga yang sehat dan sejahtera (Maryunani, 2016).

Berdasarkan hasil penelitian dan teori diatas, sejalan dengan penelitian Maryati Dewi, dkk tentang Pengaruh Edukasi Gizi terhadap Feeding Practice Ibu Balita Stunting Usia 6-24 Bulan, menyebutkan bahwa, hasil penelitian didapatkan bahwa terdapat perbedaan rerata yang bermakna pada skor pengetahuan sebelum dan setelah intervensi pada kedua kelompok $(p=0,006 ; \quad p=0,003), \quad$ terdapat perbedaan rerata yang bermakna pada skor feeding practice sebelum dan setelah intervensi pada kedua kelompok ( $p=0,002 ; p=0,05)$.

Berdasarkan hasil penelitian dan pembahasan diatas, maka menurut peneliti sebelum diberikan edukasi gizi rata-rata feeding practice ibu dengan balita Di Puskesmas Simpang Agung Kecamatan Seputih Agung Kabupaten Lampung Tengah Tahun 2020 , Rata-Rata Feeding Practice Balita Stunting Usia 6-24 Bulan Sebsudah Diberikan Edukasi Gizi adalah 40,83

Pengaruh Pemberian Edukasi Gizi Terhadap Feeding Practice Ibu Balita Stunting Usia 6-24 Bulan

Berdasarkan uji statistic, diketahui $p$-value 0,000 atau $p$-value $<0,05$, yang artinya ada Pengaruh Pemberian Edukasi Gizi Terhadap Feeding Practice Ibu Balita Stunting Usia 6-24 Bulan $\mathrm{Di}$ Puskesmas Simpang Agung Kecamatan Seputih Agung Kabupaten Lampung Tengah Tahun 2020.

bagian $\begin{array}{cc}\text { Edukasi gizi } & \text { merupakan } \\ \text { kegiatan } & \text { pendidikan }\end{array}$ kesehatan, didefinisikan sebagai upaya terencana untuk mengubah perilaku individu, keluarga, kelompok dan masyarakat dalam 
bidang kesehatan. Academic Nutrition and Dietetics (AND) mendefinisikan edukasi gizi sebagai suatu proses yang formal untuk melatih kemampuan klien atau meningkatkan pengetahuan klien dalam memilih makanan, aktifitas fisik, dan perilaku yang berkaitan dengan pemeliharaan atau perbaikan kesehatan (Kemenkes, RI. 2017).

Edukasi gizi kepada balita usia 0 hingga 24 bulan merupakan salah satu intervensi yang dapat diberikan mengingat pada usia tersebut merupakan usia emas kehidupan. Kajian intervensi gizi terhadap stunting membuktikan bahwa perbaikan intervensi terhadap tumbuh kejar linier yang berupa peningkatan panjang badan tidak dapat langsung diamati. Berdasarkan data dari Kemenkes RI (2017), perubahan dapat diamati pada saat anak tersebut berusia dari 24 bulan. Adanya catch-up setelah usia 24 bulan merefleksikan ketersediaan makanan, pola konsumsi, komposisi zat gizi yang cukup serta terhindar dari infeksi. Dengan demikian edukasi gizi harus juga ditekankan pada pencegahan terhadap infeksi (Kemenkes, RI. 2017)

Pemberian makan yang yang terlambat oleh ibu akan berdampak kepada kekurangan zat besi dan zinc pada bayi yang dalam penelitian ini hal tersebut tidak dikaji. Intervensi edukasi gizi mencakup pemberian pengetahuan dan pemberian motivasi ke arah perubahan sikap dan perilaku pemberian makan. Edukasi gizi dengan media berupa booklet dan contoh langsung (food sample) akan lebih mudah dipahami oleh subjek penelitian karena menarik perhatian dan tidak membosankan. Hal ini diperlihatkan oleh kedua kelompok melalui peningkatan skor pengetahuan dan feeding practice. Menurut ahli indera, $75 \%$ hingga $87 \%$ pengetahuan manusia disalurkan melalui indera pandang (Kemenkes, RI. 2017) Menurut penelitian Maryati Dewi, dkk tentang Pengaruh Edukasi Gizi terhadap Feeding Practice Ibu Balita Stunting Usia 6-24 Bulan, menyebutkan bahwa, hasil penelitian didapatkan bahwa terdapat perbedaan rerata yang bermakna pada skor pengetahuan sebelum dan setelah intervensi pada kedua kelompok $(p=0,006 ; p=0,003)$, terdapat perbedaan rerata yang bermakna pada skor feeding practice sebelum dan setelah intervensi pada kedua kelompok ( $p=0,002 ; p=0,05)$. Berdasarkan hasil penelitian, maka menurut peneliti edukasi gizi sangat memberikan pengaruh terhadap feeding practice ibu terhadap anaknya, hal ini dapat diketahui melalui nilai selisih dalam hasil penelitian yaitu 13,700, hal ini membuktikan bahwa nilai selisih yang besar menandakan adanya interaksi atau imbal balik yang dihasilkan oleh suatu perlakuan yaitu pemberian edukasi gizi.

\section{KESIMPULAN}

Berdasarkan hasil penelitian diatas, maka kesimpulan dalam penelitian ini adalah: Diketahui bahwa Di Puskesmas Simpang Agung Kecamatan Seputih Agung Kabupaten Lampung Tengah Tahun 2020, rata-rata Feeding Practice sebelum diberikan edukasi gizi adalah 27,13 dengan standar deviasi 8,978 dan standar eror 1,639, sedangkan sesudah diberikan edukasi gizi rata rata Feeding Practice adalah 40,83 dengan standar deviasi 10,923 dan standar error 1,994. Diketahui berdasarkan hasil rata-rata sebelum dan sesudah, nilai selisihnya adalah 13,700. Berdasarkan uji statistic, diketahui $p$-value 0,000 atau $p$-value $<0,05$, yang artinya ada Pengaruh Pemberian Edukasi Gizi Terhadap 
Feeding Practice Ibu Balita Stunting Di Puskesmas Simpang Agung Kecamatan Seputih Agung Kabupaten Lampung Tengah Tahun 2020.

\section{SARAN}

Berdasarkan hasil kesimpulan diatas, maka saran yang harus peneliti berikan adalah sebagai berikut: Bagi Tempat Penelitian.Diharapkan hasil penelitian ini dapat digunakan sebagai bahan koreksi bagi tempat penelitian untuk mengevaluasi dalam Pengaruh Edukasi Gizi Terhadap Feeding Practice pada Ibu dengan Balita Stunting Bulan dengan cara lebih rutin melakukan kegiatan edukasi gizi minimal 1 minggu 1 kali, dan mengadakan kelas khusus untuk ibu-ibu yang mengalami kendala dalam memberikan makan pada anak, serta melakukan evaluasi terhadap pertumbuhan dan perkembangan anak setiap bulannya. Bagi Responden, hasil penelitian ini diharapkan agar responden lebih rutin lagi dalam mengunjungi pelayanan kesehatan serta lebih rutin lagi dalam mengikuti edukasi gizi, sehingga pengetahuan dan pengalaman ibu dapat bertambah baik.

\section{DAFTAR PUSTAKA}

Arikunto S, 2010. Prosedur penelitian. Jakarta. Rineka cipta

Aprina. (2015). Metode Riset Penelitian. Bandar Lampung: 3G Cetak.

Fikawati, S., Wahyuni, D., Syafiq, A., Kajian, P., Masyarakat, F. K., \& Indonesia, U. (2012). Status gizi ibu hamil dan berat lahir bayi pada kelompok

vegetarian. Makara

kesehatan, 16(1), 29-35.

Hastono, (2007). Analisis data kesehatan. FK Universitas Indonesia
Kristiyanasari. (2010). Kebutuhan Gizi Pada Balita. Yogyakarta: Nuha Medika.

Kementrian Kesehatan Republik Indonesia. (2017). Profil Kesehatan. Jakarta: Departemen Kesehatan.

Maryunani, A. (2016). Manajemen Kebidanan Terlengkap. CV Trans Info Media: Jakarta.

Dewi, M., \& Aminah, M. (2016). Pengaruh Edukasi Gizi terhadap Feeding Practice Ibu Balita Stunting Usia 6-24 Bulan (The Effect of Nutritional Knowledge on Feeding Practice of Mothers Having Stunting Toddler Aged 6-24 Months). Indonesian Journal of Human Nutrition, 3(1), 18.

Notoatmodjo, S. (2014). Metodologi Penelitian Kesehatan. Jakarta: Rineka Cipta.

Notoatmodjo,

S. (2014). Promosi Kesehatan Dan Perilaku Kesehatan Edisi 1. Jakarta : Rineka Cipta.

Proverawati, A., \& Rahmawati, E. (2010). Kapita selekta ASI dan menyusui. Yogyakarta: Nuha Medika, 9, 13-17.

Profil Dinas Kesehatan Provinsi Lampung. (2016). Data Profil Kesehatan. Lampung.

Profil Dinas Kesehatan Kabupaten Lampung Tengah. (2018). Data Profil Kesehatan. Lampung Tengah.

Sulistyoningsih, H. (2011). Gizi untuk kesehatan ibu dan anak. Yogyakarta: Graha Ilmu, 128.

Setiadi, S., \& Dermawan, A. C. (2007). Konsep dan penulisan riset keperawatan. Yogjakarta: Graha Ilmu.

Sulistyaningsih. 2011. Metodologi Penelitian Kebidanan Kuantitatif- 
Kualitatif.

Edisi

I. Yogyakarta.

Susilowati, K. (2016). Gizi Dalam Daur Kehidupan. PT Refika Aditama: Bandung.

Utami, F. A., \& Gz, S. (2018). Best of The Best MPASI Gizi Tepat. Buku Edukasi.

Yuniastuti, Ari. (2018). Gizi Dan Kesehatan. Yogyakarta: Graha Ilmu.

Zami \& Febry, (2018). MP-ASI With Love Makanan Pendamping ASI Terlengkap. Jakarta Selatan: Wahyu Media. 